\title{
O debate continua...
}

\author{
The debate continues...
}

\section{Joana Azevedo da Silva Ana Sílvia Whitaker Dalmaso}

Mais do que uma réplica, aproveitamos a nova oportunidade para comentar alguns pontos que julgamos relevantes e para dialogar com algumas das importantes questões levantadas pelos debatedores.

Tomemos, como ponto de partida, as falas de sujeitos do Programa Nacional de Agentes Comunitários de Saúde que abrem o texto: elas são exemplares da amplitude da estratégia e indicadoras da complexidade da expectativa em relação ao trabalho do agente comunitário de saúde. A partir de inserções bastante diferentes no Programa, um mais na formulação e outro mais na realização, no dia-a-dia, naquele momento (1991), já apontavam para os desafios de um projeto em nascimento. Assinalavam a utopia da transformação social, transcendendo o campo específico da saúde.

Se, de um lado, o PSF é, hoje, uma estratégia do Estado para a consolidação do SUS, de outro, ele exige conteúdos de programa. Desdobrar princípios e diretrizes em modos de fazer é uma exigência colocada para as áreas sociais. O planejamento, $O$ desenvolvimento de tecnologias, a gerência e a avaliação são instrumentos básicos de atuação. Além disso, na área de formação de recursos humanos, mais do que a escolaridade formal, o perfil e as competências dos agentes comunitários são definidos conforme o leque de finalidades e de expectativas em relação ao seu trabalho. Como em outros campos novos, muitas vezes começamos mais pela negação - não fazer isto, não ser aquilo - e menos pela afirmação; a diferenciação é construída no processo.

Se o PSF se instala pelo plano da atenção primária, a reformulação do sistema de saúde não se dá por contigüidade, mas exige uma política de transformação. Mais do que um projeto nacional, a dimensão local é capaz de apreender melhor as necessidades, organizar trabalhos e articular ações. Temos acompanhado um processo de descentralização da formação de recursos humanos, mas também a permanência de uma relativa centralização do modelo assistencial.

Se, no plano dos saberes, há uma diferenciação básica na concepção de doença e de saúde, entre o conhecimento clínico e o da saúde pública, no plano das práticas trabalhase com finalidades e instrumentos específicos. O PSF toma de um e de outro os recursos necessários para a sua atuação. Em vez da funcionalidade complementar, há, como aponta Nogueira, tensão entre dois paradigmas opostos. De um lado, podemos somar esforços para desenvolver tecnologias mais adequadas, de outro, há a dinâmica social, os valores e os modos de andar a vida, os quais não são passíveis de instrumentalização.

Investir na capacitação e, especialmente, na supervisão e sistematizar resultados são formas de acumular experiências e de produzir conhecimentos e, ao mesmo tempo, de visualizar limites e construir possibilidades, o que, sem dúvida, os programas implantados estão empenhados em fazer.

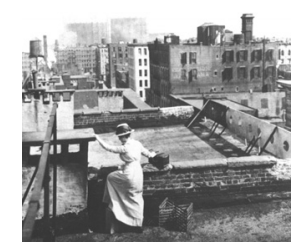



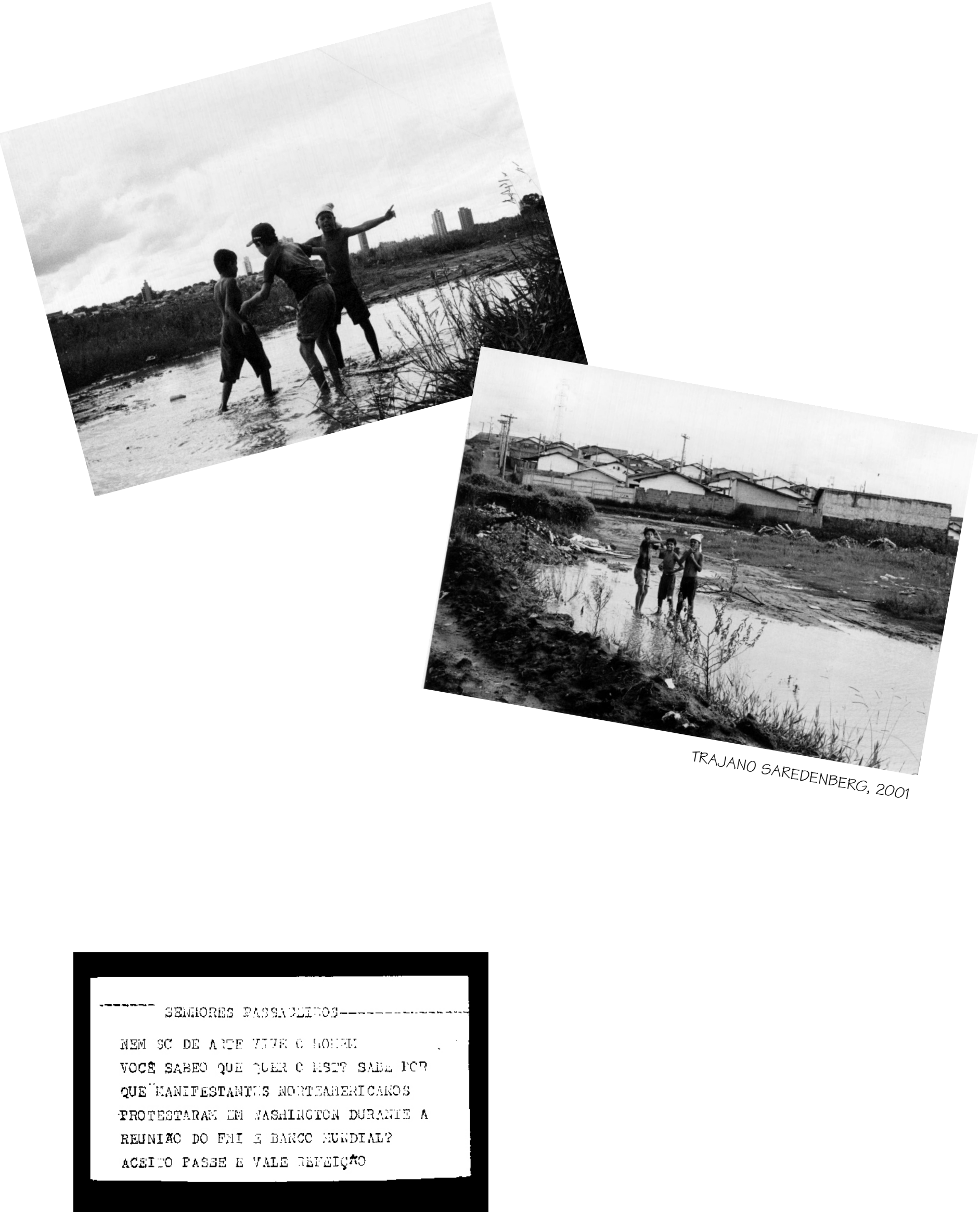

Papeleta em xerox, de Jailtão, 1999. Utilizando a tática dos pedintes de vale transporte. 